\title{
PERFORMANCE EVALUATION OF IRRIGATION SYSTEM IN CIKEUSIK IRRIGATION AREA, CIREBON REGENCY WEST JAVA PROVINCE
}

\author{
Amrizal, Umboro Lasminto and Bahmid Tohari \\ Department of Civil Engineering, Sepuluh Nopember Institute of Technology, Surabaya, Indonesia \\ E-Mail: filanet82@yahoo.co.id
}

\begin{abstract}
West Java Province is known as an area that plays an important role in agricultural production in Indonesia. Cirebon is a district in West Java which is in the eastern part bordering Central Java. Many areas of irrigation or Irrigation Network who experience a decrease in performance, one of whom who experience decreased performance is Cikeusik Irrigation Area. This time, the Irrigation Cikeusik Management implemented by Balai Besar Wilayah Sungai (BBWS) Cimanuk Cisanggarung, Directorate General of Water Resources, Ministry of Public Works and Public Housing. The Irrigation Cikeusik receive water supplies from Dam Cikeusik in the Cisanggarung river with the area in 6899 Ha. The purpose of this research is to analyze and calculate what percentage in the performance of the Sub Regional Irrigation Maneunteung West and Sub Regional Irrigation Maneunteung East on irrigation area Cikuesik using the Regulation of the Minister of Public Works No. 32 / PRT / M / 2007 on Guidelines for Operation and Maintenance of Irrigation. Some aspects of the irrigation system set out in the Regulation of the Minister of Public Works No. 32 / PRT / M / 2007 are physical infrastructure, plant productivity, supporting facilities Maintenance Operation, Maintenance Organization Operations personnel, documentation and water user associations (P3A). The research method is by direct observation, questionnaire and test methods research is done by Structural Equation Modeling (SEM). The performance evaluation of irrigation systems shows the percentage of different figures. Assessment is based on a survey conducted in West Sub Maneunteung irrigation area is $75.95 \%$ and $71.70 \%$ based on the respondent data. A difference of $4.26 \%$, thus the performance of the irrigation system is ranged between $71.70 \%$ up to $75.95 \%$ or an average of $73.82 \%$. Assessment is based on a survey conducted in Sub irigation area East Maneunteung is $76.10 \%$, while $72.41 \%$ of respondents based on the data.The difference of $3.69 \%$, thus the performance of the irrigation system is ranged between $72.41 \%$ up to $76.10 \%$ or an average of $74.26 \%$. Based on the percentage of those with regulation of the Minister Public Works No. 32/PRT/M/2007 condition Sub irrigation area West Maneunteng and East Maneunteung have good performance..
\end{abstract}

Keywords : Irrigation area of Cikeusik, Sub irigation area west Maneunteung and Sub irigation area East Maneunteung, Aspect Irrigation System, Structrual Equation Modeling (SEM)

\section{INTRODUCTION}

West Java Province is known as an area that plays an important role in agricultural production in Indonesia. From the data of Regional Irrigation which is located in West Java province numbered 855 spread over 27 districts / cities. Cirebon is a district in West Java which is located in the eastern part bordering Central Java. In the agricultural sector, Cirebon Regency is one of the rice-producing areas are located in the path of the North Coast (northern coast). Many Regional Irrigation or Irrigation Network decreased performance among those who experienced a decline in performance is Regional Irrigation Cikeusik.

Regional Irrigation Cikeusik located in the River Basin (WS) Cimanuk Cisanggarung, Watershed (DAS) Cisanggarung. while administratively located in Cirebon. Currently Regional Irrigation Cikeusik management is carried out by the Central River Region (BBWS) Cimanuk Cisanggarung, the Directorate General of Water Resources, Ministry of Public Works and Public Housing.

Regional Irrigation Cikeusik in the operations Irrigation is divided into irrigation Network West Maneunteung and irrigation Network East Maneunteung as shown in Figure 1. Performance Irrigation Network Cikeusik (irrigation Network West Maneunteung and irrigation Network East Maneunteung) is estimated to have decreased its operating performance. This performance degradation is very influential in the smooth running and operation of the irrigation water that will eventually affect the production of rice Regional irrigation Cikeusik.

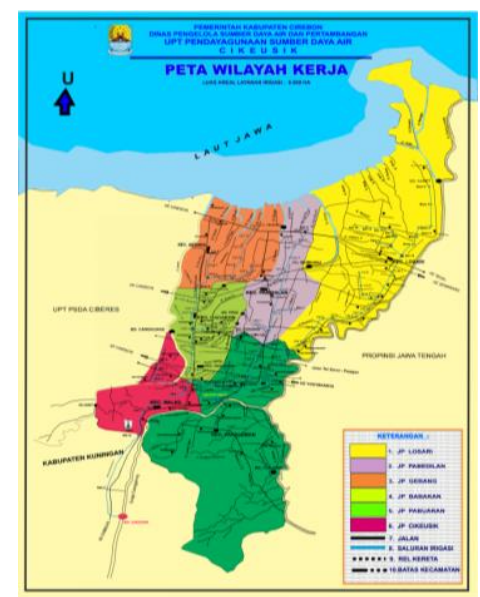

Figure-1. Location Map Of Irrigation Areas Cikeusik

\section{LITERATURE REVIEW \\ Asset Management}

Asset management is the overall process of managing assets in relation to the asset itself or an asset to the community in the surrounding areas. This process is always there during the life cycle (Life Cycle) of these assets with the aim to optimize the function of assets to provide services and improving quality of life (Leong, 2004). Asset management cycle refers to the stages inundated field SIDLACOM (Survey, Investigation, Design, Land Acquisition, Construction, Operation and 
Maintenance) and supported by the Monitoring and Evaluation and Disposal / Renewal, as shown in Figure 2.

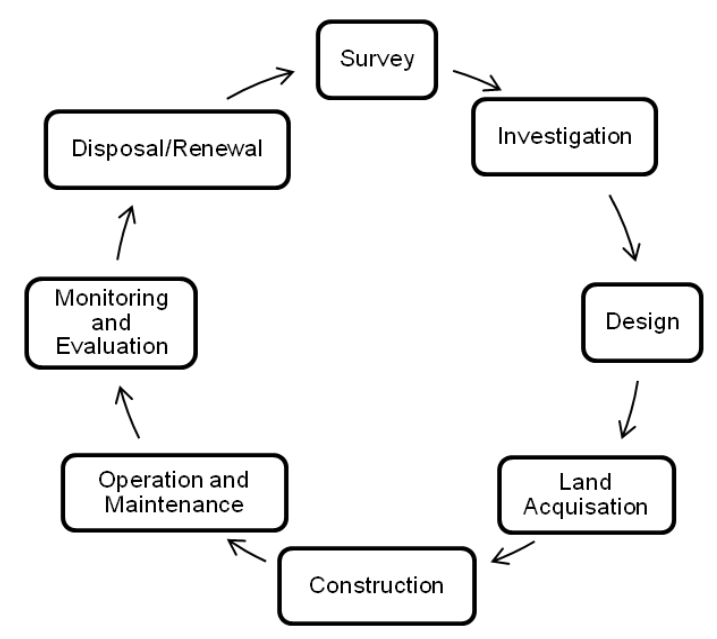

Figure-2. Asset Management

\section{Asset Management Of Irrigation}

Asset management of irrigation is part of asset management is a systematic and structured management processes for planning maintenance and funding for the irrigation system in order to achieve a defined level of services and sustainable use of water for irrigation and irrigation network users with financing irrigation asset management as efficient as possible (Regulation PUPR No. 12/PRT/M/2015 about Exploitation and maintenance of the Irrigation Network).

\section{Performance Evaluation Of Irrigation System}

Performance evaluation of irrigation system in question is an action or activity to find out the condition of the irrigation system performance compared with the standard plan. As for the performance of the condition of the total of such components in the following description.

1. The physical Network Infrastructure of irrigation Conditions

2. The condition of the Crop Productivity (irrigation water usage results)

3. Condition of means of Supporting the operation and maintenance of irrigation Network (OP)

4. Conditions of Personnel/Organization Implementing Irrigation Network CO-OP

5. Condition of the Irrigation Network Documentation

6. Institutional Conditions P3A

Operation and maintenance manual of the Central River basin (BBWS) Cimanuk Cisanggarung, performance irrigation systems are classified as in the following details.

1. The condition either classification performance (steady) when the indicator shows the level of irrigation network servicing functions $80 \%-100 \%$.

2. The conditions of classification performance is fairly level indicator shows when the functions of the Ministry of irrigation network 50\%-79\%.

3. The conditions of classification performance is lacking in function level indicator shows the Ministry of irrigation network 0-49\%.
Irrigation network performance is heavily influenced by the physical condition of the building, the function of the channel, and other factors related to the management of the irrigation network.Irrigation system performance assessment is part of the management of irrigation and assessment is usually conducted once a year with a view to monitoring the functions and performance of all aspects of the irrigation system. This assessment was carried out by the regional manager Irrigation in accordance with their respective authority.

Performance evaluation of irrigation system surroundings of the Ministry of public works and Housing, Directorate General of water resources has been set in the regulation of the Minister of public works no. 32/PRT/M/2007. Performance assessment are grouped in 6 (six) aspects as in following details.

1. Physical Infrastructure

2. The productivity of the plant

3. The supporting Operation and Maintenance (OM)

4. Personnel/Organizations Implementing OM

5. Documentation

6. Institutional Conditions water user associations (P3A)

\section{The concept of Structural Equation Modeling (SEM)}

Analysis using Structural Equation Modeling (SEM), performed to elucidate more thoroughly the relationship between variables that exist in the study. SEM is used instead to devise a theory, but rather is intended to examine and justify a model. Therefore, the main requirement using SEM is to build a hypothetical model that consists of the structural model and the measurement model in diagram form paths based justification theory. SEM is a set of statistical techniques that allow testing of a series of relationships simultaneously. The relationship established between one or more independent variables (Santoso 2011). Two reasons underlying the use of SEM is (1) SEM has the ability to estimate the relationship between variables that are multiple relationships. This relationship is formed in the structural model (relationship between the dependent and independent constructs).(2) SEM has the ability to describe the pattern of the relationship between latent constructs and manifest variables or variable indicator

\section{METHODS}

Location Research

Location of research is in the area of irrigation Cikeusik located in Cirebon regency, West Java province. The total area of irrigated area Cikeusik based on data BBWS Cimanuk Cisanggarung is 6899 ha. As for the large number of districts and raw rice on 6 interpreter Cikeusik DI water ( 7 subdistricts) are shown in Table 1 below.

Table 1. the Interpreter Irrigation in Cikeusik

\begin{tabular}{|r|l|l|c|}
\hline \multirow{2}{*}{ No. } & \multirow{2}{*}{ Interpreter } & districts & $\begin{array}{c}\text { Extensive Raw } \\
\text { Rice (Ha) }\end{array}$ \\
\hline \multirow{2}{*}{1} & \multirow{2}{*}{ Cikuesik } & Ciledug & 411 \\
\cline { 3 - 4 } & & Waled & 217 \\
\hline 2 & Losari & Losari & 1933 \\
\hline 3 & Pabedilan & Pabedilan & 1554 \\
\hline 4 & Gebang & Gebang & 1055 \\
\hline
\end{tabular}


The $2^{\text {nd }}$ International Conference on Civil Engineering Research (ICCER) 2016

"Contribution of Civil Engineering toward Building Sustainable City"

\begin{tabular}{|r|l|l|r|}
\hline 5 & Pabuaran & Pabuaran & 850 \\
\hline 6 & Babakan & Babakan & 879 \\
\hline \multicolumn{2}{|l|}{ Total } & 6899 \\
\hline
\end{tabular}

Source: Dinas (PSDAP) Kabupaten Cirebon

\section{Study Design}

In this study the steps taken to achieve the objectives described in the flow diagram as shown in Figure 3.

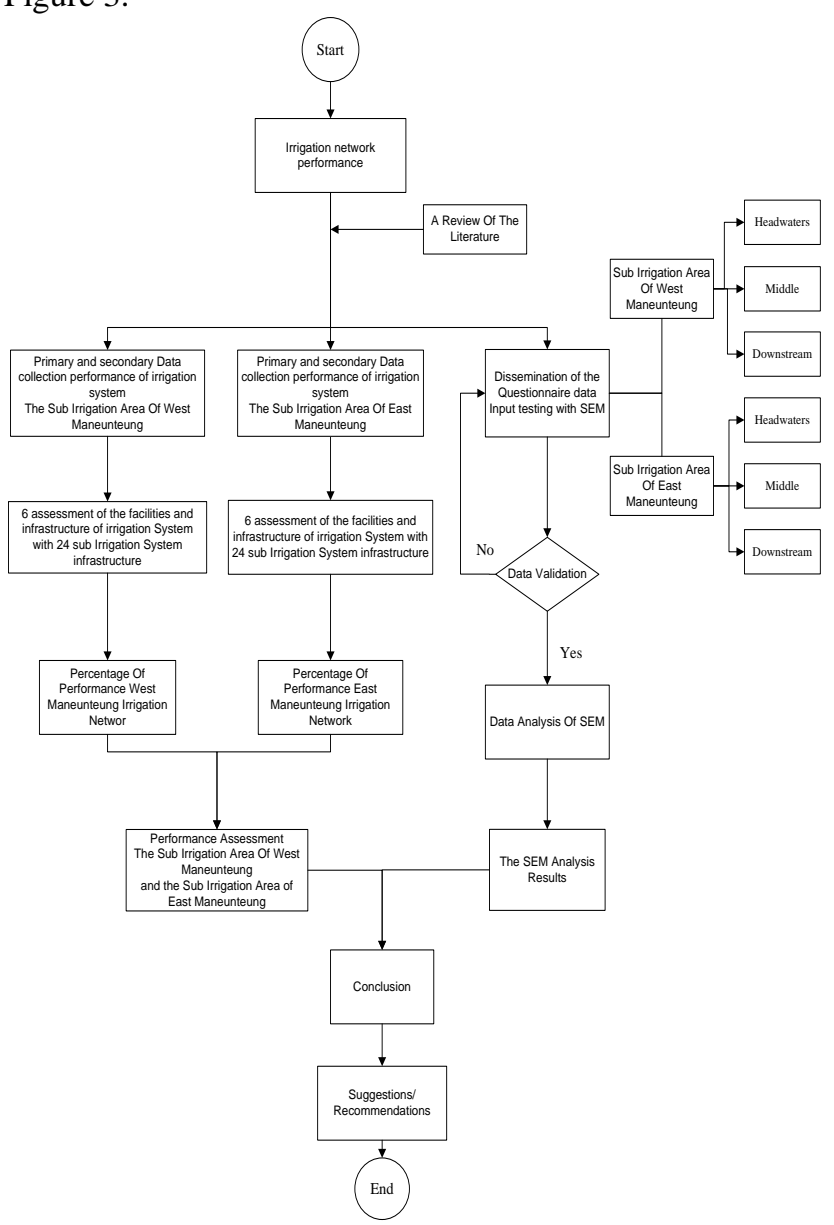

Figure-3. Study Design

\section{Preparation Of Diagram Lines}

Diagram of the latent variable path variable and scalable performance level Irrigation Areas used in this research is as described in Figure 4.

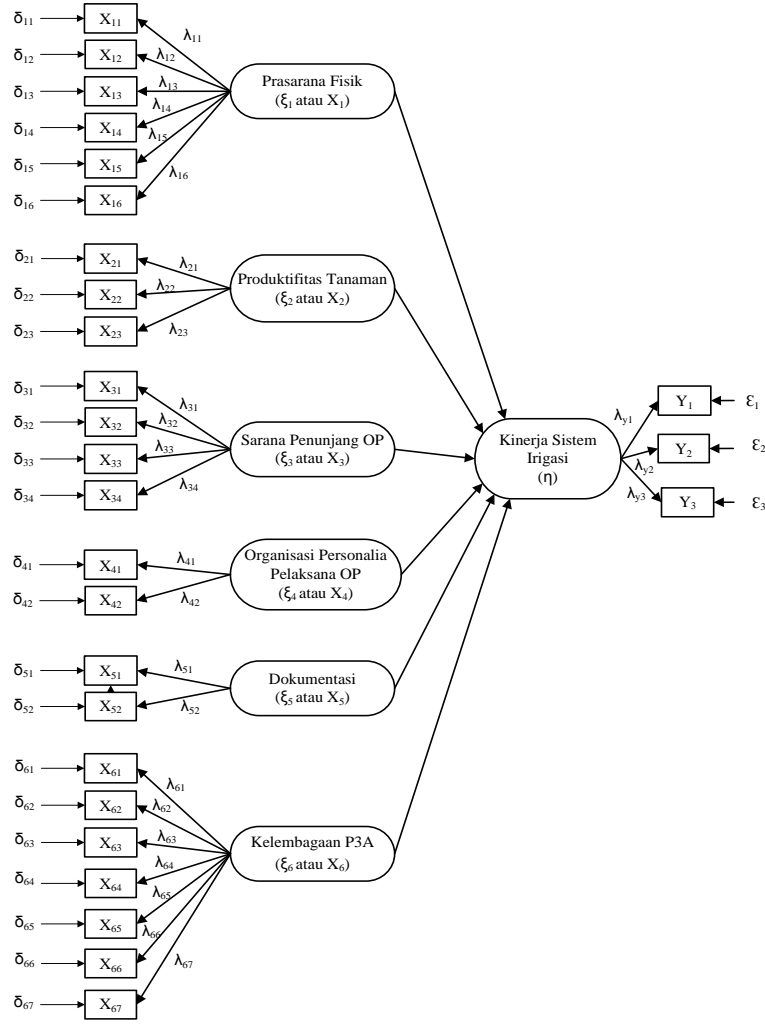

Figure-4. Path Diagram

Description for figure 4:

$\xi$ : latent variables exogenous

$\mathrm{X}$ and $\mathrm{Y}$ : measured variable

$\delta:$ measurement error

$\lambda$ : weighting coefficient factor variable

The data collected get from several related institutions, PSDAP Cirebon district, River Basin Development Agency Cimanuk Cisanggarung,UPT PSDA Cikeusik and all other related agencies. Types of data collected include:

1. Primary Data: existing conditions of irrigation networks and Questionnaire.

2. Secondary Data: Secondary data obtained through literature review and data assets irrigation (weirs, channel, retrieval building, measure buildings and complementary buildings), a map of the area of irrigation, the irrigation area scheme

\section{Data Analysis}

Data analysis in this study conducted on primary data and secondary data. Based on secondary data obtained on condition eksiting irrigation network. irrigation network West Maneunteung and East Maneunteung, will be analyzed descriptively to give a description of the condition Irigation Area of Cikeusik (Sub irigation area West Maneunteung and East Maneunteung). While the primary data analysis was conducted confirmatory factor analysis.This analysis is used to test the construct (construct) or latent variables that can not be measured directly and objectives confirmatory factor analysis was to confirm or test the model, the measurement model formulation derived from the theory.

If the model of the confirmatory analysis of hypothesized already meets the criteria of appropriateness, then be discussed aspects of the performance of the irrigation system. The primary data analysis is done on the 
results of questionnaires. In this study, data processing for this confirmatory factor analysis using the software Statistical Product and Service Solutions (SPSS) AMOS (Analysis of Moment Structures) is used as a common approach to data analysis in Structural Equation Model (Structural Equation Model), known as SEM. By using the Amos complex calculations in the SEM will be much easier than using other software. AMOS is suitable for this analysis because it can analyze the test hypotheses about the relationship between the measured variables (observation) and latent variables.

\section{RESULT AND DISCUSSIONS}

General condition of the irrigation Area Cikeusik

Irrigation area Cikeusik is at Cirebon district which is part of the province of West Java which is located in the eastern part and is the limit, as well as the gates of the Central Java province. Viewed from ground level/daratannya can be distinguished into two parts, the first lowland areas are generally located along the northern coast of the island of Java, that Gegesik, Kaliwedi, Kapetakan, Arjawinangun, Panguragan, Klangenan, Gunung jati, Tengah Tani, Weru, Astanajapura, Pangenan, Karangsembung, Waled, Ciledug, Losari, Babakan, Gebang, Palimanan, Plumbon, Depok and district Pabedilan. While some are included in the area of the plateau.

Based on its geographical location, the region of Cirebon Regency is located at position $108^{\circ} 40^{\prime}$ use $108^{\circ} 48$ ' East longitude and $6^{\circ} 30^{\prime}-7^{\circ} 00$ ' South latitude, bordered by:

- North region bordering of Indramayu Regency

- Northwest region bordering of Majalengka Regency

- South region bordering of Kuningan Regency

- East region bordered by the city of Cirebon and Brebes Regency of Central Java Province

Cikeusik Irrigation network has an area of raw rice 6899 Ha service. In Cikeusik got water from Weirs Cikeusik in river Cisanggarung. The purpose of the construction of Weirs Cikeusik is for the provision of irrigation water and prevent flooding. For the provision of irrigation water discharge is planned at Weirs Cikeusik amounting to 1500 liters/second.

Data analysis of existing conditions of irrigation system performance based on the regulation of the Minister of public works no. 32/PRT/M/2007 on guidelines for the operation and maintenance of the network irigai the terms of 6 important components namely Physical Infrastructure, the aspect of Growing Productivity, Supporting OP Aspect, the aspect of the Organization's human resources OP, aspects of Documentation and Assembly of Water Users Farmers (P3A). This stage is carried out to find out the condition of the existing performance management of irrigation in the irrigation Cikuesik Area with the region of $6899 \mathrm{Ha}$ which consists of Sub in Maneunteung West of 2562 Ha and Maneunteung in Eastern 4337Ha Sub.

\section{Assessment Of The Performance Of The Irrigation} Network West Maneunteung and East Maneunteung

Assessment of the performance of the The Irrigation Network West Maneunteung done by tracing a network of irrigation. The results of the assessment of the performance of the Sub irrigation area West Maneunteung area show on table and the results of the assessment of the performance of the Sub irrigation are East Maneunteung covers 6 aspects i.e. physical infrastructure aspects, aspects of productivity cropping, supporting OP personnel implementing the organizational aspects, documentation and $\mathrm{P} 3 \mathrm{~A}$ in show table 3.

Table 2. Performance Index West Maneunteung Irrigation Network

\begin{tabular}{|c|l|c|c|}
\hline \multirow{2}{*}{ No. } & \multicolumn{1}{|c|}{ Description } & $\begin{array}{c}\text { The Value Of Standard } \\
\text { Weights }\end{array}$ & $\begin{array}{c}\text { Condition } \\
\text { Value } \\
\text { Weighting }\end{array}$ \\
\cline { 3 - 4 } & & \multicolumn{1}{c}{$\mathbf{\%})$} & $(\mathrm{CVW})$ \\
\hline $\mathbf{1}$ & $\mathbf{2}$ & $\mathbf{3}$ & $\mathbf{4}$ \\
\hline & Total & $\mathbf{1 0 0}$ & $\mathbf{7 5 , 9 5}$ \\
\hline I & Physical Infrastructure & 15 & 33,81 \\
\hline II & The Productivity Of Cropping & 15 & 12,85 \\
\hline III & Support OM & 15 & 7,60 \\
\hline IV & Personnel Organizations OM & 5 & 11,10 \\
\hline V & Documentation & 10 & 3,70 \\
\hline VI & Assembly Of Farmer Water Users (P3A) & & 6,90 \\
\hline
\end{tabular}

Table 3. Performance Index East Maneunteung Irrigation Network

\begin{tabular}{|c|l|c|c|}
\hline \multirow{2}{*}{ No. } & \multicolumn{1}{|c|}{ Description } & $\begin{array}{c}\text { The Value Of Standard } \\
\text { Weights }\end{array}$ & $\begin{array}{c}\text { Condition } \\
\text { Value } \\
\text { Weighting }\end{array}$ \\
\cline { 3 - 4 } & & \multicolumn{1}{|c|}{$(\%)$} & $(\mathrm{CVW})$ \\
\hline 1 & \multicolumn{1}{|c|}{$\mathbf{3}$} & $\mathbf{4}$ \\
\hline & Total & 100 & 76,10 \\
\hline I & Physical Infrastructure & 45 & 33,98 \\
\hline II & The Productivity Of Cropping & 15 & 12,82 \\
\hline III & Support OM & 10 & 7,60 \\
\hline IV & Personnel Organizations OM & 15 & 11,10 \\
\hline V & Documentation & 5 & 3,70 \\
\hline VI & Assembly Of Farmer Water Users (P3A) & 10 & 6,90 \\
\hline
\end{tabular}

Criteria for the determination of the value of the irirgasi system performance based on Regulation of PU No. 32/PRT/M/2007 are described as follows:

1. The value weights between $80-100$ excellent performance

2. The value of weight between $70-79 \operatorname{good}$ performance

3. The value weights between $55-69$ performance less

4. The value weights between $<54$ is ugly performance and need attention

Calculation of Irrigation system performance assessment in the West Maneunteung is 75,95\%. Whereas the calculation of the performance assessment system of Irrigation in East Maneunteung have value 76,10\%. Based on the value in the network then the criteria seen Irrigation Maneunteung Irrigation Network of West and East Maneunteung has good performance.

The analysis and Test Data the respondents based on Structural Equation Modeling (SEM)

In analysis and test data on respondents will be explained about the steps undertaken in the analysis and 
test data with respondents using model Structural Equation Modelling (SEM) as well as software Statistical Product and Service Solution (SPSS) AMOS (analysis of Moment Structures). Of the review of the literature and a framework of thought that has been described in the previous chapter, subtitles in general models of SEM regarding penilitian has 6 independent variables (Exogenous) and 1 dependent variable (Endogenous) and 3 variable results (Depend).

Six independent variables in question is the physical Infrastructure (X 1 or $\xi 1$ ), crop Productivity (X 2 or $\xi 2$ ), means of Supporting OP (X 3 or $\xi 3$ ), the Organization Implementing the human resources OP (X 4 or $\xi 4$ ), documentation (X 5 or $\xi 5$ ), documentation (X 6 or $\xi 6)$, while the dependent variable is the performance of irrigation systems ( $\eta$ ) and variable results (depend) Qmax/Qmin is the index increased pertanaman (Y1), increasing crop yields (Y2), vast underserved water increases (Y3). Of the variables are arranged in the form of flowcharts.

The flowchart of the next structural equations are compiled, and continued with determination technique of estimation. This technique is done gradually through the estimation model by means of the technique of measurment confirmatory factor analysis and structural equation models continued with. It is intended to look at the suitability of the model and the relationship of causality to be built.

Test Data Analysis with confirmatory At this stage of the analysis will be performed to test for multidimensional confirmatory of an invalid constructs with latent variables. Each Analysis is also testing the validity of a theoretical invalid constructs. Each latent variable used in the study was formed based on the theoretical concepts with several indicators or manifest. Analysis of confirmatory further test whether such indicators is a valid indicator of measuring latent as invalid constructs. In other words, whether the indicators are the mutidimension of a latent, or invalid constructs instead of mutidimension.

The next step is testing or analysis of the model of SEM in full. Testing the model against the Structural Equation Models (SEM) performed with two testing, i.e. testing the suitability of the model and test of significance test of regression coefficient through causality. Model used for analysis is a model of recursive model where all arrows have one direction without rotation of the feedback, so as not to be correlated with other variables. Calculation analysis of confirmatory performed using SPSS software version AMOS ver. 21 as shown in Figure 5.

Description for figure 5 are:

$\xi$ : latent variables exogenous

$\mathrm{X}$ and $\mathrm{Y}$ : measured variable

$\delta:$ measurement error

$\lambda$ : weighting coefficient factor variable

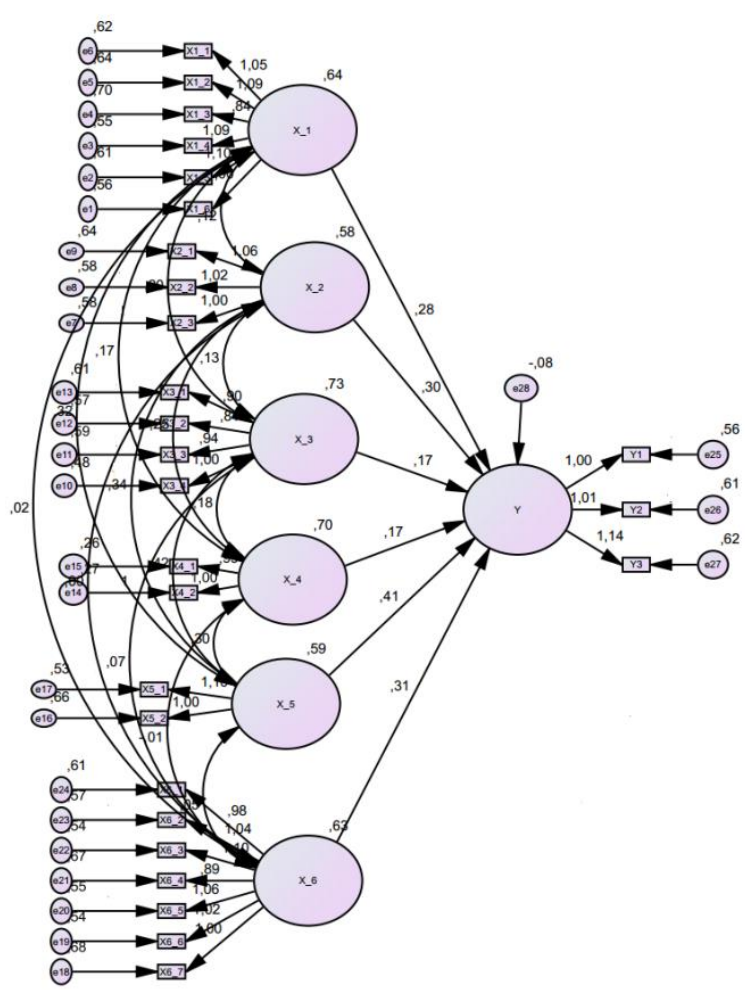

Figure-5. analysis of SEM

\section{Test Data validation With level 2 Confirmatiry} Analysis

Analysis of factors confirmatiory the second level in this study was used to test the indicators of all the variables that make up the overall model. In this study, there is a latent variable 6 or independent, i.e. indicators which affect the performance of irrigation systems, which include: Physical Infrastructure (X 1 or $\xi 1$ ) Cropping, productivity (X 2 or $\xi 2$ ), Supporting OM (X 3 or $\xi 3$ ), organization of human resources OP (X 4 or $\xi 4)$, documentation (X 5 or $\xi 5)$, P3A Condition (X 6 or $\xi 6$ ) which as a whole consists of the 24 observed variable as variable constituent and 1 endogenous variable observed variables, with 3 as a variable result. In the result above the value $\mathrm{p}$ all variables $\mathrm{X}=* * *<0.05$ so that $\mathrm{H} 0$ is rejected and the $\mathrm{H} 1$ is accepted, which means that the all variables $X$ positive and significant effect against the variable $\mathrm{Y}$.

\section{Data Normality Test With Univariate and Multivariate Normality}

In terms of the distribution of the test evaluation over data normality assumption is if the value in the column critical ratio (c.r.) is no greater than \pm 2.58 , then it can be said that the distribution of the data is not normal. Because evaluation is carried out using the criteria of normality critical ratio skewness value of \pm 0.01 significance level at 2.58 . The data can be said to have a normal distribution if the value of the critical ratio skewness value under the absolute price 2.58 .

From the results as shown table 4 , the analysis of the value normality critical skewness value, almost all indicators has a value smaller than c.r. \pm 2.58 . Thus, it can be said that in all of the univariate Gaussian. 
Table 4. Normality Test

\begin{tabular}{|c|c|c|c|c|c|c|}
\hline Variable & $\min$ & $\max$ & skew & c.r. & kurtosis & c.r. \\
\hline $\mathrm{Y} 3$ & 1 & 5 & $-0,444$ & $-2,981$ & $-0,714$ & $-2,394$ \\
\hline Y2 & 1 & 5 & $-0,361$ & $-2,425$ & $-0,856$ & $-2,871$ \\
\hline Y1 & 1 & 5 & $-0,425$ & $-2,853$ & $-0,702$ & $-2,353$ \\
\hline X6_1 & 1 & 5 & $-0,258$ & $-1,729$ & $-0,845$ & $-2,834$ \\
\hline X6_2 & 1 & 5 & $-0,285$ & $-1,914$ & $-0,809$ & $-2,712$ \\
\hline X6_3 & 1 & 5 & $-0,369$ & $-2,478$ & $-0,741$ & $-2,487$ \\
\hline X6_4 & 1 & 5 & $-0,398$ & $-2,67$ & $-0,583$ & $-1,955$ \\
\hline X6_5 & 1 & 5 & $-0,316$ & $-2,118$ & $-0,806$ & $-2,704$ \\
\hline X6_6 & 1 & 5 & $-0,191$ & $-1,281$ & $-1,082$ & $-3,628$ \\
\hline X6_7 & 1 & 5 & $-0,207$ & $-1,39$ & $-0,765$ & $-2,566$ \\
\hline X5_1 & 1 & 5 & $-0,471$ & $-3,162$ & $-0,546$ & $-1,832$ \\
\hline X5_2 & 1 & 5 & $-0,458$ & $-3,076$ & $-0,638$ & $-2,141$ \\
\hline X4_1 & 1 & 5 & $-0,601$ & $-4,035$ & $-0,279$ & $-0,934$ \\
\hline X4_2 & 1 & 5 & $-0,69$ & $-4,629$ & $-0,207$ & $-0,693$ \\
\hline X3_1 & 1 & 5 & $-0,344$ & $-2,307$ & $-0,628$ & $-2,107$ \\
\hline X3_2 & 1 & 5 & $-0,131$ & $-0,881$ & $-0,872$ & $-2,925$ \\
\hline X3_3 & 1 & 5 & $-0,319$ & $-2,14$ & $-0,784$ & $-2,628$ \\
\hline X3_4 & 1 & 5 & $-0,296$ & $-1,985$ & $-0,84$ & $-2,817$ \\
\hline X2_1 & 1 & 5 & $-0,338$ & $-2,267$ & $-0,798$ & $-2,677$ \\
\hline$X 2 \_2$ & 1 & 5 & $-0,266$ & $-1,786$ & $-0,882$ & $-2,959$ \\
\hline$X 2 \_3$ & 1 & 5 & $-0,443$ & $-2,97$ & $-0,514$ & $-1,725$ \\
\hline $\mathrm{X} 1 \_1$ & 1 & 5 & $-0,33$ & $-2,216$ & $-0,913$ & $-3,062$ \\
\hline $\mathrm{X} 1 \_2$ & 1 & 5 & $-0,397$ & $-2,66$ & $-0,772$ & $-2,59$ \\
\hline $\mathrm{X} 1 \_3$ & 1 & 5 & $-0,284$ & $-1,905$ & $-0,554$ & $-1,857$ \\
\hline$X 1 \_4$ & 1 & 5 & $-0,288$ & $-1,93$ & $-0,891$ & $-2,987$ \\
\hline X1_5 & 1 & 5 & $-0,37$ & $-2,479$ & $-0,735$ & $-2,465$ \\
\hline X1_6 & 1 & 5 & $-0,258$ & $-1,728$ & $-0,876$ & $-2,938$ \\
\hline Multivariate & & & & & 43,4 & 9,01 \\
\hline
\end{tabular}

Reliability Test with the test Construct of Reliability

Test the Construct of Reliability that is testing the reliability and consistency of the data meets the criteria in Cronstruct Reliability $>0.7$. The value of the Construct of Reliability among up to 0.60 .7 can still be accepted on condition the validity of invalid constructs (indicators) in the model is good.

Table 5. Reliability Test

\begin{tabular}{|c|c|c|}
\hline $\begin{array}{c}\text { Dimensions and } \\
\text { variables }\end{array}$ & $\mathrm{CR}>0,7$ & Conclusion \\
\hline $\mathrm{X} 1 \_1$ & 0,903 & Reliability \\
\hline $\mathrm{X} 1 \_2$ & 0,908 & Reliability \\
\hline$X 1 \_3$ & 0,912 & Reliability \\
\hline$X 1 \_4$ & 0,877 & Reliability \\
\hline$X 1 \_5$ & 0,905 & Reliability \\
\hline X1_6 & 0,903 & Reliability \\
\hline $\mathrm{X} 2 \_1$ & 0,809 & Reliability \\
\hline X2_2 & 0,812 & Reliability \\
\hline$X 2 \_3$ & 0,811 & Reliability \\
\hline X3_1 & 0,878 & Reliability \\
\hline X3_2 & 0,858 & Reliability \\
\hline X3_3 & 0,840 & Reliability \\
\hline X3_4 & 0,849 & Reliability \\
\hline $\mathrm{X} 4 \_1$ & 0,857 & Reliability \\
\hline $\mathrm{X} 4 \_2$ & 0,859 & Reliability \\
\hline X5_1 & 0,732 & Reliability \\
\hline$X 5 \_2$ & 0,772 & Reliability \\
\hline X6_1 & 0,907 & Reliability \\
\hline X6_2 & 0,918 & Reliability \\
\hline X6_3 & 0,921 & Reliability \\
\hline $\mathrm{Y} 1$ & 0,819 & Reliability \\
\hline $\mathrm{Y} 2$ & 0,813 & Reliability \\
\hline Y3 & 0,831 & Reliability \\
\hline
\end{tabular}

As shown table 5, Reliability analysis on the output results Contruct Reliabiity (CR), all values $>0.7$, so it can be inferred that all the variables are invalid constructs is Reliability.

\section{Irrigation System performance assessment Manual and Data based on Respondents}

Table 6. Performance of West Maneunteung Irrigation Network

\begin{tabular}{|c|c|c|c|c|}
\hline \multirow[t]{2}{*}{ No. } & \multirow[t]{2}{*}{ Description } & $\begin{array}{c}\text { The Value Of Standard } \\
\text { Weights }\end{array}$ & $\begin{array}{c}\text { Condition } \\
\text { Value } \\
\text { Weighting } \\
\end{array}$ & $\begin{array}{l}\text { Assessment } \\
\text { Based 0n } \\
\text { Respondents }\end{array}$ \\
\hline & & $(\%)$ & $(\%)$ & $(\%)$ \\
\hline 1 & 2 & 3 & 4 & \\
\hline & Total & 100 & 75,95 & 71,70 \\
\hline $\mathrm{I}$ & Physical Infrastructure & 45 & 33,81 & 32,09 \\
\hline II & The Productivity OfCropping & 15 & 12,85 & 10,51 \\
\hline III & Support OM & 10 & 7,60 & 7,12 \\
\hline IV & Personnel Organizations OM & 15 & 11,10 & 11,42 \\
\hline V & Documentation & 5 & 3,70 & 3,58 \\
\hline $\mathrm{VI}$ & Assembly Of Farmer Water Users (P3A) & 10 & 6,90 & 6,97 \\
\hline
\end{tabular}

Table 7. Performance of East Maneunteung Irrigation Network

\begin{tabular}{|c|l|c|c|c|}
\hline \multirow{2}{*}{ No. } & \multirow{2}{*}{ Description } & $\begin{array}{c}\text { The Value Of Standard } \\
\text { Weights }\end{array}$ & $\begin{array}{c}\text { Condition } \\
\text { Value } \\
\text { Weighting }\end{array}$ & $\begin{array}{c}\text { Assessment } \\
\text { Based 0n } \\
\text { Respondents }\end{array}$ \\
\cline { 3 - 5 } & \multicolumn{1}{|c|}{2} & $(\%)$ & $(\%)$ & $(\%)$ \\
\hline 1 & & 100 & 7 & \\
\hline & Total & 45 & 33,10 & 72,41 \\
\hline I & Physical Infrastructure & 15 & 12,82 & 31,85 \\
\hline II & The Productivity Of Cropping & 10 & 7,60 & 7,83 \\
\hline III & Support OM & 15 & 11,10 & 11,86 \\
\hline IV & Personnel Organizations OM & 5 & 3,70 & 3,64 \\
\hline V & Documentation & 10 & 6,90 & 7,16 \\
\hline VI & Assembly OfFarmer Water Users (P3A) & & & \\
\hline
\end{tabular}

From figure 4, table 6 and table 7, assessment of the performance of irrigation systems showed the percentage of different. figures. Assessment based on a survey conducted on the Sub in the West is Maneunteung $75.95 \%$ whereas based on the data of the respondents $71.70 \%$. The difference amounting to $4.26 \%$, thus the performance of irrigation systems is in the range $71.70 \%$ s/d $75.95 \%$ or an average of $73,82 \%$.Assessment based on a survey conducted in East Maneunteung in the Sub is $76.10 \%$ whereas based on the data of the respondents $72,41 \%$. The difference amounted to $3,69 \%$, thus the performance of irrigation systems is in the range $72.41 \%$ s/d $76.10 \%$ or an average of $74,26 \%$. Use of Structural Equation Modeling (SEM) in the test data and test analysis model, against the respondent data to evaluate a success implementing an activity showed satisfactory results.

\section{CONCLUSIONS}

Based on the results of this study the following conclusions are drawn :

1. The performance of irrigation systems in terms of Physical Infrastructure, productivity aspects of cultivation, the means of supporting the Organization's Personnel, OP OP, documentation and 
conditions on P3A Sub In Manenuteung West has percentage $75.95 \%$ and Sub in Eastern Manenuteung have perosentase $76.10 \%$. The percentage based on Candy PU No. 32? PRT/M/2007 fall into the category of good performance.

2. Irrigation system performance assessment shows the percentage of different figures. Assessment based on a survey conducted on the Sub in the West is Maneunteung $75.95 \%$ whereas based on the data of the respondents $71.70 \%$. The difference amounting to $4.26 \%$, thus the performance of irrigation systems is in the range $71.70 \% \mathrm{~s} / \mathrm{d} 75.95 \%$ or an average of $73,82 \%$. Assessment based on a survey conducted in East Maneunteung in the Sub is $76.10 \%$ whereas based on the data of the respondents $72,41 \%$. The difference amounted to $3,69 \%$, thus the performance of irrigation systems is in the range $72.41 \% \mathrm{~s} / \mathrm{d}$ $76.10 \%$ or an average of $74,26 \%$.

3. The success of the irrigation system performance must also be supported by community participation in activities either in $\mathrm{P} 3 \mathrm{~A}$ meetings/conferences, follow the search network irrigation, the irrigation network improvements and natural disasters, the dues for tertiary irrigation network improvements and planning layout plans and patterns of cultivation.

4. Use of Structural Equation Modeling (SEM) in the test data and test analysis model, against the respondent data to evaluate a success implementing an activity showed satisfactory results.

5. for the performance of irrigation systems can serve with optimal periodic examination is required on each wall, repair irrigation network channels water door seta suffered damage and also outreach to farmers about the importance of irrigation are maintained and not to be abused or tampered with

6. In this study, the authors obtained the percentage of ratings with both categories are expected to next year, BBWS Cimanuk Cisanggarung have to able to manage Cikeusik Irrigation area so as not to experience a decrease as well as be able to archive data related to evaluation of materials for Cikeusik Irirgation are for better performance in the coming year.

\section{REFERENCES}

[1] Ministry of Public Works and Public Housing. 2007. Regulation of The Minister of Public Works and Public Housing No. 32/PRT/M/2007 (20, guidelines for the operation and maintenance of irrigation Networks.. Secretary of Ministry of Public Works and Public Housing, Jakarta.

[2] Ministry of Public Works and Public Housing. 2015. Regulation of The Minister of Public Works and Public Housing No. 12/PRT/M/2015, Exploitation and maintenance of the Irrigation Network. Secretary of Ministry of Public Works and Public Housing, Jakarta.

[3] Byrne, Barbara M., (2010), Structural Equation Modeling with AMOS: Basic Concepts, Applications, and Programming, 2nd ed, Routledge Taylor \& Francis, New York.
[4] Hair, Joseph F et al., (2006), MultiVariate Data Analysis, Fifth Edition. Gramedia Pustaka Utama, Jakarta.

[5] Stolovitch, Harold D., and Keeps, Erica J., (1992), Handbook of Human Performance Technology A Comprehensive Guide for Analysis and Solving Performance Problem in Organizations, Jersey-Bass Publisher, San Francisco.

[6] Wuensch, K.L., (2006), Conducting a path analysis with SPSS/Amos (p. 15), GreeDept. of Pasychology, East Carolina University. 